American Journal of Biochemistry and Biotechnology 6 (1): 19-24, 2010

ISSN 1553-3468

(C) 2010 Science Publications

\title{
Do Resistin and Tumor Necrosis Factor- $\alpha$ Relate to Changes in Insulin Resistance in Normal Pregnancy?
}

\author{
${ }^{1}$ Parvin Zareian, ${ }^{2}$ Abdolreza Sotoodeh Jahromi, ${ }^{2}$ Fateme Hemati Rad and ${ }^{1}$ Safar Zarei \\ ${ }^{1}$ Department of Physiology, \\ ${ }^{2}$ Department of Immunology, \\ Jahrom University of Medical Sciences, Jahrom Iran \\ ${ }^{3}$ Department of Obestetrics and Gynecology, Honary Clinic, Jahrom, Iran
}

\begin{abstract}
Problem statement: The purpose of this study was to evaluate the role of resistin and Tumor Necrosis Factor- $\alpha$ (TNF- $\alpha$ ) in insulin resistance during pregnancy. Approach: Serum resistin and TNF- $\alpha$ concentrations were measured by ELISA in 86 healthy pregnant women (26, 23 and 37 of them in the 1st, 2nd and 3rd trimesters, respectively) and in 21 healthy non pregnant women in a cross sectional study. Results: Resistin concentration was significantly higher in the third trimester $\left(9.5 \pm 3.3 \mathrm{ng} \mathrm{mL}^{-1}\right)$ as compared with non pregnant women $\left(7 \pm 3.3 \mathrm{ng} \mathrm{mL}^{-1}\right)$. Serum TNF- $\alpha$ level were also significantly increase in pregnant women $\left(2.6 \pm 1.9 \mathrm{pg} \mathrm{mL}^{-1}\right)$ as compared with maternal healthy controls $\left(0.8 \pm 0.7 \mathrm{pg} \mathrm{mL}^{-1}\right)$. There were significant correlation between gestational age and BMI $(\mathrm{r}=0.28, \mathrm{p}=0.01)$, resistin $(\mathrm{r}=0.36, \mathrm{p}=0.002)$ and TNF- $\alpha(\mathrm{r}=-0.44, \mathrm{p}<0.0001)$. There was not significant correlation between gestational age and Insulin Resistance (IR). We also did not found correlation between IR and resistin as well as between IR and TNF- $\alpha$ in pregnant women. Conclusion: TNF- $\alpha$ and resistin do not appear to contribute greatly to pregnancy induced insulin resistance in healthy pregnancy.
\end{abstract}

Key words: Resistin, TNF- $\alpha$, pregnancy, insulin resistance

\section{INTRODUCTION}

Pregnancy is related to glucose metabolism disorders and insulin resistance (Hadden and McLaughlin, 2009; Johnson, 2008; Stanley et al., 1998). Insulin resistance may facilitate supply of appropriate nutrients particularly of glucose to fetus for fetal growth and metabolism. The mechanism responsible for insulin resistance has not been clearly stated. Recent researches have been shown adipokinins include leptin (McLachlan et al., 2006) resistin (Lu et al., 2006; Caja et al., 2005) IL-6 (Senn et al., 2002) and TNF- $\alpha$ (Zinman et al., 1999; Kirwan et al., 2002; Melczer, 2002; Gwozdziewiczová et al., 2004) play an important role in insulin resistance. TNF- $\alpha$ is one of the most widely studied cytokinins produce by adipose tissue. This cytokinin is also secret by placenta (ZavalzaGómez et al., 2008; Chen et al., 1991). TNf- $\alpha$ has an important role in obesity-induced insulin resistance and diabetes (Pereira et al., 2006; Zinman et al., 1999; Gwozdziewiczová et al., 2004; 2005). A few studies suggest that TNF- $\alpha$ may play role in insulin resistance in normal and diabetogenic pregnant women (Pereira et al., 2006; Xue-Lian et al., 2008; Kirwan et al., 2002). Resistin is another protein identified recently as a hormone secreted by adipocytes which has a controversial history regarding its role in the pathogenesis of obesity-mediated insulin resistance and type 2 diabetes (Lu et al., 2006; Hasegawa et al., 2005; Hivert et al., 2008). Insulin sensivity changes from an enhanced state during early pregnancy to an insulin resistant state in late pregnancy (Kirwan et al., 2002; Leturque et al., 1984; Stanley et al., 1998). Therefore it is inspected, subsequent to increase in IR during pregnancy, its related factors change, too. However, at the time of our study a few researches have been done about changes in serum resistin and TNF- $\alpha$ level during different trimesters of normal pregnancy and their relationships to insulin resistance. Therefore, the aim of this study was to examine whether serum TNF$\alpha$ and resistin concentration change during normal pregnancy and, if so, to relate those changes corresponding alterations in insulin resistance and BMI.

Corresponding Author: Abdolreza Sotoodeh Jahromi, Department of Immunology, Jahrom University of Medical Sciences, Jahrom, Iran Tel: +98-791-3340406 Fax: +98- 791-3341509 
Am. J. Biochem. \& Biotech., 6 (1): 19-24, 2010

\section{MATERIALS AND METHODS}

This cross sectional study was done on eighty-six pregnant women with different gestational ages (first trimester: 26, second trimester: 23 , third trimester: 37 and twenty-one healthy non pregnant women similar in age and BMI (control group: $23.8 \pm 0.8$, patient groups: $23 \pm 0.6)$. All subjects met the following criteria: No history of pre-gestational diabetes; no history of liver, respiratory, thyroid or other illness and any current infectious condition. They were not on any medical therapy.

Body Mass Index (BMI, $\mathrm{Kg} \mathrm{m}^{-2}$ ) was calculated according to the maternal height and pre-pregnancy weight. Serum samples were analyzed for concentrations of resistin, TNF- $\alpha$, insulin and glucose. Serum glucose was measured by GOD-POD method. Serum insulin was determined by ELISA (Diaplus). Serum resistin was measured by ELISA (Biovender, Germany Ref NO: RD 191016100R) and also serum TNF- $\alpha$ was assayed by ELISA (Bender med, Austria Ref NO: BMF 223). Insulin resistance value were calculated using the homeostasis model assessment, HOMA-IR, as (fasting insulin $\mathrm{IU} \mathrm{L} \mathrm{L}^{-1}$ ) $\times$ (fasting glucose mmol $\mathrm{L}^{-1}$ ) $/ 22.5$ as previously reported by Matthews et al. (1985). All participants in the trial gave informed consent and the study was approved by University Ethics committee.

Statistical analysis: All results are displayed as Mean \pm SEM (standard error of mean). Levene's test was shown there was not difference between groups. One way ANOVA analysis and Post hoc tests were used to compare mean among the groups and correlations were calculated using liner correlation (Pearson). Statistical analysis was performed using SPSS 12 for window. $\mathrm{P}<0.05$ was considered statistically significant for all analysis.

\section{RESULTS}

A total of 86 pregnant women and 21 non pregnant subjects participated in the study. Clinical and laboratory characteristics of patients and controls are summarized in Table 1. BMI were found to be significantly increased in the 3rd trimester as compared with controls and women with 1st trimester of pregnancy (Fig. 1a and Table 2). Patients in the second and third trimester of pregnancy had significantly higher systolic pressure than non pregnant women (Fig. 1b). Serum resistin concentration were found to be significantly raised in the second and third trimester as compared with women with first trimester of pregnancy, but we were not found any statistical difference in serum resistin concentration between the healthy controls and patients with gestational age less than 24 weeks (Table 2 and Fig. 1c). TNF- $\alpha$ level was also significantly higher in patients in all gestational age as compared non pregnant women (Fig. 1d). However, during pregnancy TNF- $\alpha$ level were significantly decreased with increase in gestational age (Table 2). Patients exhibited higher score of HOMA IR compared control group, but there were not difference in this score between pregnant subjects in different gestational age (Table 1 and 2). There were significant correlation between gestational age and BMI $(\mathrm{r}=0.28, \mathrm{p}=0.01)$, diastolic pressure $(\mathrm{r}=0.28$, $\mathrm{p}=0.01)$ resistin $(\mathrm{r}=0.36, \mathrm{p}=0.002)$ and $\mathrm{TNF}-\alpha$ level $(\mathrm{r}=-0.44, \mathrm{p}<0.0001)$. There was not significant correlation between gestational age and IR. Resistin level in pregnancy did not correlate with IR, fasting insulin, BMI and body weight. TNF- $\alpha$ level also did not correlate with IR, fasting insulin, BMI and body weight.

Table 1: Clinical and laboratory characteristic of patients and control

\begin{tabular}{lcc}
\hline & $\begin{array}{c}\text { Pregnant women } \\
\text { Mean } \pm \text { SE }\end{array}$ & $\begin{array}{c}\text { Control } \\
\text { Mean } \pm \text { SE }\end{array}$ \\
\hline Number of case & 86.0 & 21.0 \\
Age (year) & $26.4 \pm 0.500$ & $27.20 \pm 1.30$ \\
Gestational age (week) & $23.9 \pm 1.200$ & 0.00 \\
HT $(\mathrm{m})$ & $1.6 \pm 0.007$ & $1.58 \pm 0.01$ \\
WT $(\mathrm{Kg})$ & $65.0 \pm 1.300^{* *}$ & $58.60 \pm 1.50$ \\
BMI $\left(\mathrm{Kg} \mathrm{m}{ }^{-2}\right)$ & $25.4 \pm 0.400^{*}$ & $23.40 \pm 0.70$ \\
SBP $\left(\mathrm{mmHg}^{*}\right)$ & $117.0 \pm 0.900^{* *}$ & $110.70 \pm 1.50$ \\
DBP $(\mathrm{mmHg})$ & $72.8 \pm 0.800$ & $70.90 \pm 3.40$ \\
BGL $\left(\mathrm{mg}^{*} / 100\right)$ & $81.5 \pm 1.700$ & $80.20 \pm 1.90$ \\
Insulin $\left(\mu \mathrm{LU} \mathrm{mL}^{-1}\right)$ & $10.9 \pm 0.600$ & $8.70 \pm 0.40$ \\
Resistin $\left(\mathrm{ng} \mathrm{mL} \mathrm{mL}^{-1}\right)$ & $8.3 \pm 0.300$ & $7.00 \pm 0.70$ \\
TNF $\left(\mathrm{pg} \mathrm{mL} \mathrm{mL}^{-1}\right)$ & $2.8 \pm 0.200^{* * *}$ & $0.80 \pm 0.10$ \\
IR & $2.1 \pm 0.100^{* *}$ & $1.70 \pm 0.10$
\end{tabular}

BMI: Body Max Index; HT: Height of women; WT: Weight of body; SBP: Systolic Blood Pressure; DBP: Diastolic Blood Pressure; BGL: Blood Glucose Level; IR: Insulin Resistance; *: p<0.05 (control); **: $\mathrm{p}<0.01$ (control); ***: $\mathrm{p}<0.0001$ (control)

Table 2: Clinical and laboratory characteristics of pregnant women with different gestational age

\begin{tabular}{|c|c|c|c|}
\hline & $\begin{array}{l}\text { 1st trimester } \\
\text { Mean } \pm \text { SE }\end{array}$ & $\begin{array}{l}\text { 2nd trimester } \\
\text { Mean } \pm \mathrm{SE}\end{array}$ & $\begin{array}{l}\text { 3rd trimester } \\
\text { Mean } \pm \text { SE }\end{array}$ \\
\hline Number of cases & 26.00 & 23.00 & 37.00 \\
\hline Age (year) & $25.50 \pm 0.87$ & $24.90 \pm 0.50$ & $27.60 \pm 0.80$ \\
\hline GA (week) & $11.20 \pm 0.30$ & $22.20 \pm 2.70$ & $32.90 \pm 0.80$ \\
\hline WT (Kg) & $59.20 \pm 2.20$ & $65.70 \pm 3.10$ & $68.20 \pm 1.80 * *$ \\
\hline $\mathrm{HT}(\mathrm{m})$ & $1.58 \pm 0.01$ & $1.58 \pm 0.01$ & $1.60 \pm 0.01$ \\
\hline $\mathrm{SBP}(\mathrm{mmHg})$ & $114.20 \pm 1.90$ & $117.50 \pm 1.80$ & $118.30 \pm 1.20 *$ \\
\hline $\mathrm{DBP}(\mathrm{mmHg})$ & $70.50 \pm 1.50$ & $71.70 \pm 1.70$ & $74.70 \pm 1.10$ \\
\hline $\operatorname{BMI}\left(\mathrm{Kg} \mathrm{m}^{-2}\right)$ & $23.60 \pm 0.80$ & $25.70 \pm 0.90$ & $26.20 \pm 0.60 * *$ \\
\hline BGL (mg/100) & $78.60 \pm 1.30$ & $79.40 \pm 2.30$ & $84.10 \pm 3.50$ \\
\hline Insulin $\left(\mu \mathrm{L} \mathrm{mL}^{-1}\right)$ & $10.50 \pm 0.70$ & $10.60 \pm 0.80$ & $10.05 \pm 0.60$ \\
\hline Resistin (ng mL $\left.{ }^{-1}\right)$ & $6.70 \pm 0.20$ & $8.60 \pm 0.40 *$ & $9.50 \pm 0.50 * * *$ \\
\hline $\mathrm{TNF}\left(\mathrm{pg} \mathrm{mL} \mathrm{m}^{-1}\right)$ & $3.93 \pm 0.40$ & $2.88 \pm 0.30 *$ & $2.02 \pm 0.20 * * *$ \\
\hline IR & $2.00 \pm 0.12$ & $2.02 \pm 0.14$ & $2.10 \pm 0.01$ \\
\hline
\end{tabular}

BMI: Body Mass Index; GA: Gestational Age; WT: Wight of body during pregnancy; HT: Height; SBP: Systolic Blood Pressure; DBP: Diastolic Blood Pressure; BGL: Blood Glucose Level; IR: Insulin Resistance; *: $\mathrm{p}<0.05$; **: $\mathrm{p}<0.01$; ***: $\mathrm{p}<0.001$ (significantly different from pregnant women in 1 st trimester) 
Am. J. Biochem. \& Biotech., 6 (1): 19-24, 2010



(a)

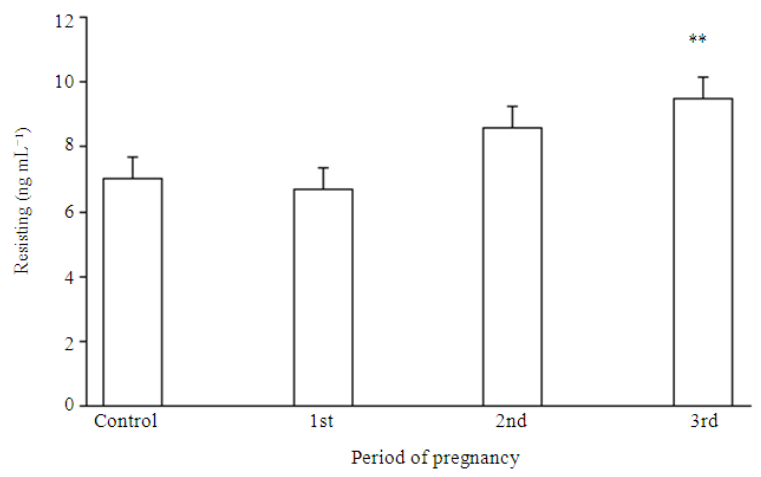

(c)

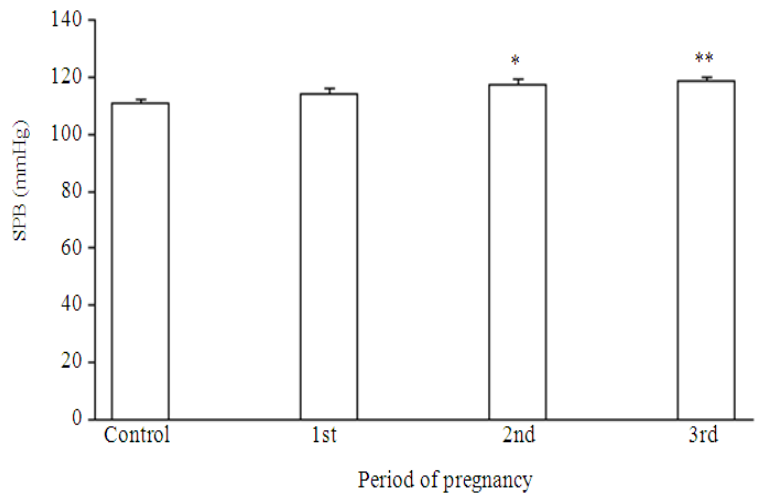

(b)

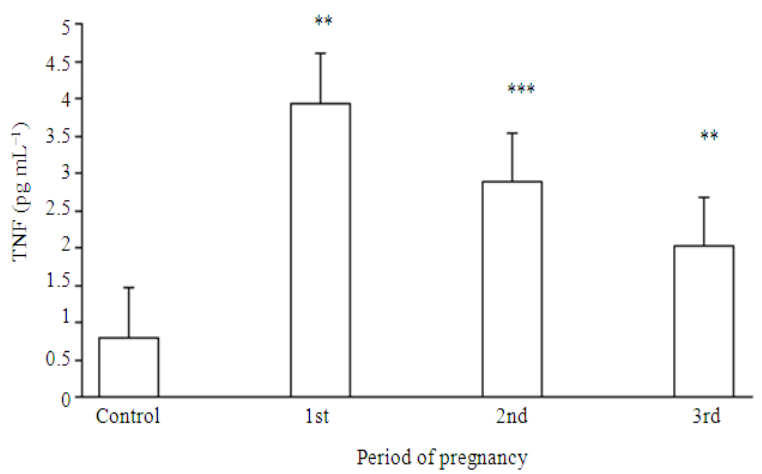

(d)

Fig. 1: (a) BMI in patients in different trimesters of pregnancy and controls. BMI were significantly higher in 3rd trimesters compared with the control $(* *: \mathrm{p}<0.01)$. (b) Systolic blood pressure in different trimesters of pregnancy and controls. Systolic blood pressure were significantly higher in the 2nd and 3rd trimesters as compared with control group $(*: \mathrm{p}<0.05, * *: \mathrm{p}<0.01)$. (c) Serum resistin level in different trimesters of pregnancy and control. Serum resistin level significantly higher in the 3rd trimester as compared control $(*: \mathrm{p}<0.05)$. (d) Serum TNF level in different trimesters of pregnancy. TNF level significantly higher in the 1st, 2nd and 3rd trimesters of pregnancy as compared control $(* * *: p<0.0001, * *: p<0.01)$

\section{DISCUSSION}

Glucose metabolism disorder is a common complication during pregnancy and its pathology is associated with IR and deficiency of insulin secretion (Johnson, 2008). In this study, insulin resistance significantly was higher in total group of healthy pregnant than in non pregnant women. In spite of previous report we did not found correlation between gestational age and insulin resistance. Kirwan et al. (2002); Melczer (2002); Stanley et al. (1998) have been shown insulin resistance was significantly increased in late pregnancy compared with either control or early pregnancy. This difference may be related to differences in dietary composition, life style between western and eastern societies (Clapp, 2006), variability between insulin assays in different experimental researches (Manley et al., 2008), differences in the population studied and sampling time during pregnancy.

A number of studies have been reported concentrations of resistin in pregnant subjects (Palik et al., 2007; Nien et al., 2007; Hendler et al., 2005; Chen et al., 2005). Our findings of higher maternal resistin concentration only in third trimester compared to non pregnant subjects and women in the first trimester are consistent with report by Chen et al. (2005) but, Palik et al. (2007) reported that differences between resistin concentration of non pregnant and pregnant women are significantly in 1st, 2nd and 3rd trimester. Higher plasma concentration of resistin in second and third trimester of pregnancy compared first trimester as well as the positive correlation with gestational age were showed that placenta has important role in resistin 
production during pregnancy. In addition a number of studies have been shown, resistin level decrease after deliver (Megia et al., 2008). In present study similar to recent reports, we could not found correlation between maternal resistin and insulin resistance (Megia et al., 2008; Kulik-Rechberger and Mora-Janiszewska, 2009; Kuzmicki et al., 2009). Our results are in agreement with several previous observations that found an increase in TNF- $\alpha$ level in pregnant as compared non pregnant subjects (Melczer, 2002; Xue-Lian et al., 2008; Daher et al., 1999) but in contradiction with these studies, we found negative correlation between gestational age and TNF- $\alpha$ level. Explanation account for this finding may be related to lifestyle of our subjects. Clapp and Kiess (2000) reported that regular weight bearing exercise during pregnancy suppressed the usual pregnancy-associated changes in the circulating level of TNF- $\alpha$ (Clapp and Kiess, 2000). In present study, most of patients were villager and naturally had high level of physical activity. In addition pregnancy to be associated with changes of several hormones, including, estrogen, progesterone, cortisol and 1, 25 dihydroxyvitamin D3 (Henricks et al., 1972; Smith et al., 1973; Ardawi et al., 1997). Some of these hormones such as cortisol and catecholamines and 1, 25 dihydroxy D3 are potent inhibitor of TNF- $\alpha$ production by monocyte/macrophage (DeRijk et al., 1997; Guirao et al., 1997; Anand et al., 2009; Ito et al., 2002). In other study has been shown, plasma concentration of cortisol was elevated more during late pregnancy than early pregnancy (Kirwan et al., 2002). Therefore it is possible increased production of these hormones during pregnancy to be responsible for reduced maternal TNF- $\alpha$ production.

\section{CONCLUSION}

In conclusion, our findings suggest that TNF- $\alpha$ and resistin do not appear to contribute greatly to pregnancy induced insulin resistance in healthy pregnancy.

\section{ACKNOWLEDGEMENT}

This research was supported by the research project of the Jahrom University of Medical Sciences (p/9/439082). Authors thank of staffs of Honary clinic, Mothary hospital (Miss Neda Abaszade and Mr. shadmand) and the women who participated.

\section{REFERENCES}

Anand, S.P., P. Selvarajand and P.R. Narayanan, 2009. Effect of 1,25 dihydroxyvitamin $\mathrm{D}_{3}$ on intracellular IFN- $\gamma$ and TNF- $\alpha$ positive T cell subsets in pulmonary tuberculosis. Cytokine, 45: 105-110. PMID: 19091593
Ardawi, M.S., H.A. Nasrat and H.S. BA'Aqueel, 1997. Calcium-regulating hormones and parathyroid hormone-related peptide in normal human pregnancy and postpartum: A longitudinal study. Eur. J. Endocrinol., 137: 402-409. PMID: 9368509

Caja, S., I. Martinez, M. Abelenda and M. Puerta, 2005. Resistin expression and plasma concentration peak at different times during pregnancy in rats. J. Endocrinol., 185: 551-559. PMID: 15930181

Chen, H.L., Y.P. Yang, X.L., Hu, K.K. Yelavarthi and J.L. Fishback et al., 1991. Tumor necrosis factor alpha mRNA and protein are present in human placental and uterine cells at early and late stages of gestation. Am. J. Pathol., 139: 327-335. PMID: 1867321

Chen, D., M. Dong, Q. Fang, H.E. Jing, Z. Wang and Z.X. Yang, 2005. Alterations of serum resistinin normal pregnancy and pre-eclampsia. Clin. Sci. 108: 81-84. PMID: 15377276

Clapp, J.F. and W. Kiess, 2000. Effects of pregnancy and exercise on concentrations of the metabolic markers tumor necrosis factor alpha and leptin. Am. J. Obstet. Gynecol. 182: 300-306. PMID: 10694328

Clapp, J.F., 2006. Effects of diet and exercise on insulin resistance during pregnancy. Metab. Syndr. Relat. Disord., 4: 84-90. PMID: 18370754

Daher, S., F. Fonseca, O.G. Ribeiro, C.C. Musatti and M. Gerbase-DeLima, 1999. Tumor necrosis factor during pregnancy and at the onset of labor and spontaneous abortion. Eur. J. Obstet. Gynecol. Reprod. Biol., 83: 77-79. PMID: 10221614

DeRijk, R., D. Michelson, B. Karp, J. Petrides, E. Galliven and P. Deuster et al., 1997. Exercise and circadian rhythm-induced variations in plasma cortisol differentially regulate Interleukin-1 beta (IL-1 beta), IL-6 and Tumor Necrosis Factor-alpha (TNF alpha) production in humans: high sensitivity of TNF alpha and resistance of IL-6. Clin. Endocrinol. Metab., 82: 2182-2191. PMID: 9215292

Guirao, X., A. Kumar, J. Katz, M. Smith, E. Lin and C. Keogh et al., 1997. Catecholamines increase monocyte TNF receptors and inhibit TNF through $\beta_{2}$-adrenoreceptor activation. Am. J. Physiol., 273: E1203-8. PMID: 9435537

Gwozdziewiczová, S., R. Lichnovská, J. Hrebícek and F. Cesk, 2004. Tumor Necrosis Factor alpha (TNF alpha) and insulin resistance. Cesk Fysiol., 53: 167-175. PMID: 15704741

Gwozdziewiczova, S., R. Lichnovska, R.B. Yahia, R. Chlup and J. Hřebiček, 2005. TNF- $\alpha$ in the development of insulin resistance and other disorders in metabolic syndrome. Biomed. Pap. Med. Fac. Univ. Palacky Olomouc Czech Repub., 149: 109-017. PMID: 16170397 
Hadden, D.R. and C. McLaughlin, 2009. Normal and abnormal maternal metabolism during pregnancy. Semin Fetal Neonatal Med., 14: 66-71. PMID: 18986856

Hasegawa, G., M. Ohta, Y. Ichida, H. Obayashi, M. Shigeta and M. Yamasaki, 2005. Increased serum resistin levels in patients with type 2 diabetes are not linked with markers of insulin resistance and adiposity. Acta Diabetol., 42: 104-109. PMID: 15944845

Henricks, D.M., J.F. Dickey, J.R. Hill and W.E. Johnston, 1972. Plasma estrogen and progesterone levels after mating and during late pregnancy and postpartum in cows. Endocrinology, 90: 1336-1342. PMID: 5012745

Hendler, I., S.C. Blackwell, S.H. Mehta, J.E. Whitty, R.N.E. Russell and Y. Sorokin et al., 2005. The levels of leptin, adiponectin and resistin in normal weight, overweight and obese pregnant wopmen with and without preeclampsia. Am. J. Obstet. Gynecol., 193: 979-983. PMID: 16157097

Hivert, M.F., L.M. Sullivan, C.S. Fox, D.M. Nathan, Sr. R.B. D'Agostino and P.W.F. Wilson et al., 2008. Associations of Adiponectin, Resistin and TNF $\alpha$ with Insulin Resistance. J. Clin. Endocrinol. Metab., 93: 3165-72. PMID: 18492747

Ito, A., A.C. Buenafe, A. Matejuk, A. Zamora, M. Silverman and J. Dwyer et al., 2002. Estrogen inhibits systemic $\mathrm{T}$ cell expression of TNF- $\alpha$ and recruitment of $\mathrm{TNF}-\alpha^{+} \mathrm{T}$ cells and macrophages into the CNS of mice developing experimental encephalomyelitis. Clin. Immun., 102: 275-282. PMID: 11890714

Johnson, C.A., 2008. Glucose homeostasis during canine pregnancy: Insulin resistance, ketosis and hypoglycemia. Theriogenology, 70: 1418-1423. PMID: 18823654

Kirwan, J.P., S. Hauguel-De Mouzon, J. Lepercq, J. Claude Challier and L. Huston-Presley et al., 2002. TNF- $\alpha$ is a predictor of insulin resistance in human pregnancy. Diabetes, 51: 2207-2213. PMID: 12086951

Kulik-Rechberger, B. and O. Mora-Janiszewska, 2009. Serum resistin concentrations in cases of gestational diabetes mellitus with good glycemic control and in cord blood. Ginekol. Pol., 80: 432-436. PMID: 19642599

Kuzmicki, M., B. Telejko, J. Szamatowicz, A. Zonenberg, A. Nikolajuk and A. Kretowski et al., 2009. High resistin and interleukin-6 levels are associated with gestational diabetes mellitus. Gynecol. Endocrinol., 25: 258-263. PMID: 19408175
Leturque, A., A.F. Burnol, P. Ferre and J. Girard, 1984. Pregnancy-induced insulin resistance in the rat: Assessment by glucose clamp technique. Am. J. Physiol., 246: E25-E31. PMID: 6364830

Lu, H.L., H.W. Wang, Y. Wen, M.X. Zhang and H.H. Lin, 2006. Roles of adipocyte derived hormone adiponectin and resistin in insulin resistance of type 2 diabetes. World J. Gastroenterol., 12: 1747-1751. PMID: 16586545

Manley, S.E., S.D. Luzio and I.M. Stratton et al., 2008. Preanalytical, analytical and computational factors affect homeostasis model assessment. Diabetes Care, 31: 1877-1883. PMID: 18535197

Matthews, D.J., J.P. Hoskers, A.S. Rudenski, B.A. Waylur, D.Y. Trencher and R.C. Turner, 1985. Homeostasis model assessment insulin resistance and B-cell function from fasting plasma glucose and insulin concentrations in man. Diabetologia, 28: 412-419. PMID: 3899825

McLachlan, K.A., D. O'Neal, A. Jenkins and F.P. Alford, 2006. Do adiponectin, TNF- $\alpha$, leptin and CRP relate to insulin resistance in pregnancy? Studies in women with and without gestational diabetes, during and after pregnancy. Diabetes Metab. Res. Rev., 22: 131-138. PMID: 16170833

Megia, A., J. Vendrell, C. Gutierrez, M. Sabaté, M. Broch and J.M. Fernández-Real et al., 2008. Insulin sensitivity and resistin levels in gestational diabetes mellitus and after parturition. Eur. J. Endocrinol., 158: 173-178. PMID: 18230823

Melczer, Z., 2002. Role of tumor necrosis factor- $\alpha$ in insulin resistance during normal pregnancy. Eur. J. Obstet. Gynecol. Reprod. Biol. 105: 7. PMID: 12270556

Nien, J.K., S. Mazaki-Tovi, R. Romero, J.P. Kusanovic, O. Erez and F. Gotsch et al., 2007. Resistin: A hormone which induces insulin resistance is increased in normal pregnancy. J. Perinat. Med., 35: 513-521. PMID: 17919114

Palik, E., E. Baranyi, Z. Melczer, M. Audikovszky, A. Szöcs and G. Winkler et al., 2007. Elevated serum acylated (biologically active) ghrelin and resistin levels associate with pregnancy-induced weight gain and insulin resistance. Diabetes Res. Clin. Pract., 76: 351-357. PMID: 17010469

Pereira, F.O., T.S. Frode and Y.S. Medeiros, 2006. Evaluation of tumor necrosis factor alpha, interleukin-2 soluble receptor, nitric oxide metabolites and lipids as inflammatory markers in type 2 diabetes mellitus. Mediators Inflamm., 2006: 39062. PMID: 16864902

Senn, J.J., P.J. Klover, I.A. Nowak and R.A. Mooney, 2002. Interleukin-6 induces cellular insulin resistance in hepatocytes. Diabetes, 51: 3391-3399. PMID: 12453891 
Smith, V.G., L.A. Edgerton, H.D. Hafs and E.M. Convey, 1973. Bovine serum estrogens, progestins and glucocorticoids during late pregnancy, parturition and early lactation. J. Anim. Sci., 36: 391-396. PMID: 4687097

Stanley, K., R. Fraser and C. Bruce, 1998. Physiological changes in insulin resistance in human pregnancy: longitudinal study with the hyperinsulinaemic euglycaemic clamp technique. Int. J. Obstetr. Gynaecol., 105: 756-759. PMID: 9692417

Xue-Lian, G., Y. Hui-Xia and Z. Yi, 2008. Variations of tumor necrosis factor- $\alpha$, leptin and adiponectin in mid-trimester of gestational diabetes mellitus. Chin. Med. J., 121: 701-705. PMID: 18701022
Zavalza-Gómez, A.B., R. Anaya-Prado, A.R. Rincón-Sánchez and J.M. Mora-Martínez, 2008. Adipokines and insulin resistance during pregnancy. Diabetes Res. Clin. Pract., 80: 8-15. PMID: 18291552

Zinman, B., A.J.G. Hanley, S.B. Harris, J. Kwan and G. Fantus, 1999. Circulating tumor necrosis factor$\alpha$ concentration in a native Canadian population with high rates of type 2 diabetes mellitus. J. Clin. Endocrinol. Metab., 84: 272-278. PMID: 9920095 